\title{
FGF10 wt Allele
}

National Cancer Institute

\section{Source}

National Cancer Institute. FGF10 wt Allele. NCI Thesaurus. Code C51423.

Human FGF10 wild-type allele is located within 5p13-p12 and is approximately 84 kb in length. This allele, which encodes fibroblast growth factor 10 protein, plays a role in wound healing and morphogenesis. 